\title{
IMÁGENES PSÍQUICAS QUE EMERGEN POR MEDIO DE LA TÉCNICA DE IMAGINACIÓN ACTIVA EN INTEGRANTES DEL SEMILLERO DE PSICOLOGÍA RELACIONAL DE LA UNIVERSIDAD CATÓLICA LUIS AMIGÓ EN LA CIUDAD DE MEDELLÍN DURANTE LA ÉPOCA DE CONFINAMIENTO DE LA PANDEMIA DEL COVID-19
}

Psychic pictures that emerge through the active imagination technique in members of the relational psychology of the Catholic University Luis Amigó from Medellin city while them stayed at home locked up during of the COVID-19 pandemic

\author{
Andrés Tadeo Marulanda Valencia \\ andres.marulandava@amigo.edu.co \\ David Ignacio Molina Velázquez \\ david.velasquezmo@amigo.edu.co \\ Universidad Católica Luis amigó \\ Psicología \\ Colombia
}

\section{RESUMEN}

Esta investigación tiene como objetivo principal describir cuáles fueron las imágenes psíquicas que emergieron en el inconsciente colectivo por medio de la técnica de imaginación activa de Carl Jung y la psicología analítica en seis integrantes del semillero de psicología relacional de la Universidad Católica Luis Amigó en la ciudad de Medellín, durante la etapa de confinamiento de la pandemia del COVID-19 antes de que finalizara la cuarentena el 30 de agosto de 2020. El proyecto realizado es de enfoque cualitativo, investigación de tipo documental de la técnica y un taller de imaginación activa a partir de la plataforma Zoom; de los datos recolectados se está realizando un análisis de las imágenes desde las expresiones arquetipales de la teoria junguiana y el muestreo realizado se hace por conveniencia. En este momento, el proceso investigativo se encuentra en análisis de los datos recolectados que emergieron y en los resultados preliminares se hallaron que están relacionadas con la incertidumbre que ha producido la pandemia en imagenes de encierro, de inestabilidad y las emociones asociadas de rabia, miedo e inseguridad.

\section{PALABRAS CLAVE:}

Imaginación activa, símbolo, imágenes psíquicas, pandemia, inconsciente colectivo, psicología analítica 
INTRODUCCIÓN

"Lo que sabemos de nosotros mismos no es todo lo que somos" Hannah, B. (1981)

La psique tiene capacidad creativa y de simbolización desde la teoría junguiana, es decir, las imágenes del inconsciente pueden tomar vida propia; estas tienen la posibilidad de personificar imágenes dependiendo del momento por el que esté atravesando la persona desde el inconsciente colectivo, como si existieran otros personajes o imágenes dentro de la psique de los individuos.

La psique y su capacidad simbólica se expresa en imágenes; parte de estas quedan accesibles a la conciencia y otra parte de ellas queda oculta en el inconsciente. La imagen es una forma para acceder al inconsciente individual con sus complejos y los arquetipos del inconsciente colectivo estudiados por la psicología analítica.

Las imágenes emergentes del inconsciente permiten resolver problemas de la cotidianidad a partir de su capacidad creativa, intuir situaciones futuras, autorregularse; permiten descubrir emociones reprimidas, expresiones arquetípicas y complejos psicológicos y la sombra personal. La psique contiene incluso mecanismos compensatorios que se manifiestan en las imágenes de los sueños. Carl Jung descubrió una técnica a partir de un trabajo personal con sus imágenes propias, llamada imaginación activa, que fue la inspiración para su libro rojo. A partir de esa búsqueda en esa experiencia personal de Jung surgió la imaginación activa, que fue una técnica de la psicología analítica para el conocimiento del propio mundo interior, descrita como:

Una forma de maduración y de autorrealización de la personalidad, liderado principalmente por el sí mismo. Se caracteriza por la confrontación de lo consciente con algunos componentes del inconsciente: con la persona, la sombra, el ánima, el ánimus y el sí mismo y la tarea básica consiste en diferenciar el yo de todos estos complejos, para lo cual este se debe relacionar objetivamente con todos ellos, evitando identificarse con ellos. El proceso conduce a una transformación paulatina de la personalidad a estadios de mayor adaptación del individuo, tanto a su realidad externa como a su realidad interna (Alonso, 2004, p.62).

Debido al momento de la pandemia hemos estado observando imágenes nuevas en el exterior que anteriormente no habíamos experimentado, como por ejemplo gente usando tapabocas en las actividades cotidianas y ahora con la pandemia a nivel interior también otras imágenes que nos están inundando como humanidad, siendo pues la técnica de imaginación activa un medio para identificarlas.

La técnica es beneficiosa para las personas que quieran conocer partes ocultas de sí mismas y alcanzar un mayor entendimiento de su psique en mayor coherencia con su esencia, y de tal manera contribuir a su proceso de individuación; finalmente es de gran importancia la imaginación activa en los procesos personales y la clínica individual y en los procesos más colectivos permite observar las imágenes que compartimos como humanidad a partir del inconsciente colectivo, en este caso, las imágenes que emergen en la pandemia del Covid 19. 
La psicología profunda ha mantenido el interés por la psique profunda y ha enfatizado por estudiar las imágenes internas en congruencia con las culturas primitivas como la mitología, para rescatar la importancia de estos saberes que tienen una conexión con la naturaleza humana y que siguen teniendo vigencia actualmente, pero que es desconocida para muchos o no tienen un valor aceptable. La desvalorización de la psique permite que las expresiones del alma sean ridiculizadas por no ser tangibles, aunque en culturas ancestrales fueron una fuente de sabiduría muy importante para el hombre: ellos utilizaron estas manifestaciones para tomar decisiones o solucionar problemas.

También fue una forma de meditación usada por el ser humano desde los albores de la historia, como medio para conocer a los dioses. En otras palabras, se trata de una técnica o método para explorar lo desconocido; ya sea que pensemos en lo desconocido como un dios externo o sea que sepamos que lo podemos encontrar mediante la contemplación de las partes desconocidas de nosotros mismos, a través de una experiencia completamente interior (Hannah,1981).

La psique está llena de imágenes que son difíciles de asimilar para la psique consciente y de difícil acceso al conocimiento humano; este ha sido estudiado en la mayoría de los casos de forma indirecta debido a que se hace difícil acceder a él y enfrentarse a imágenes psíquicas que aparecen de la realidad interna, es doloroso e incómodo enfrentarse a estas imágenes porque pueden conmover profundamente; como método consiste en un proceso en el cual se deja que aparezca la imagen y se tiene una conversación con ella preguntando por qué apareció.

La imaginación activa es un método de introspección o de meditación, con unas especiales características. Es una técnica terapéutica de la categoría del análisis de los sueños, que fue desarrollada por Carl Jung. Su procedimiento consiste en dejar fluir las imágenes, pero fijándolas y evitando, especialmente, representarse a sí mismo por una figura de la fantasía (Retamales, 2016)

A causa de los múltiples contenidos que tenemos en el inconsciente, que se denotan en imágenes y sueños recurrentes y recuerdos olvidados, surge la necesidad de utilizar un método para indagar acerca de estos contenidos que están fuera del alcance y que para recurrir a ellos se debe hacer de forma indirecta.

Esta técnica no debe confundirse con una imaginación pasiva; la imaginación activa, a partir de un estado de relajación, permite al analizar ir descubriendo formas conscientes, creativas y elaboradas, de incorporar componentes psíquicos provenientes del inconsciente generalmente manifestados a través de contenidos oníricos-. En otras palabras, dar un espacio a estos fenómenos de la mente con la finalidad de integrarlos en la psique, en lugar de negarlos o reprimirlos (Torres, 2018).

\section{MÉTODO}

La investigación realizada se hace desde el enfoque cualitativo, porque se interesa por comprender en términos generales los fenómenos estudiados. Es la técnica más utilizada propiamente en las ciencias sociales, y será abordada a partir de la investigación documental. Es importante resaltar que se elige este método desde las experiencias vividas, pues se pretende la descripción y narración a partir de la técnica de imaginación activa desde los relatos de seis integrantes del semillero de psicología relacional de la Universidad Católica Luis Amigó; cabe mencionar que el tipo de muestreo será por conveniencia, debido a que los relatos serán 


\section{Marulanda \& Molina}

recolectados y las técnicas empleadas se realizarán por medio de un ejercicio de imaginación activa y dibujos que serán analizados.

\section{RESULTADOS}

Estas fueron algunas de las imágenes que se hallaron mediante la técnica de imaginación activa, donde estas están asociadas al moviendo e inestabilidad que se denota también en la narrativa del participante en relación con la incertidumbre, desazón e inseguridad.

"Yo vi una cruz como en dos planos, un plano horizontal y en uno vertical, y se fue convirtiendo en una brújula, como un metrónomo que se movía en el plano horizontal... para dónde va esto, para dónde vamos... Como una cadena de ADN hasta que se convertía en un torbellino, lugar de desazón e inseguridad".

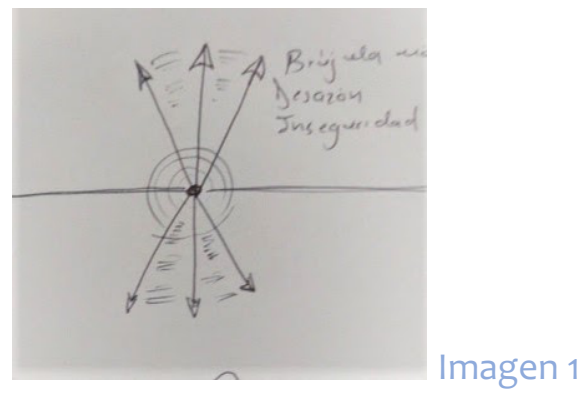

El participante 2, en su imagen hace mención de la cárcel, en contraste con la liberación de aves: "Se me vino como un pensamiento como de una cárcel, no sé por qué, como aves yéndose, ave liberándose, sentí como esa opresión, retenida como oprimida".

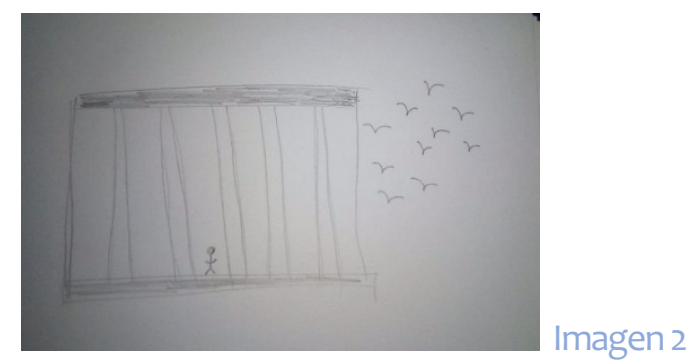

El participante 3 nombra que la imagen que se le venía en el ejercicio era un huracán, una tormenta, la incertidumbre, y que las emociones asociadas estaban relacionadas con la rabia y miedo.

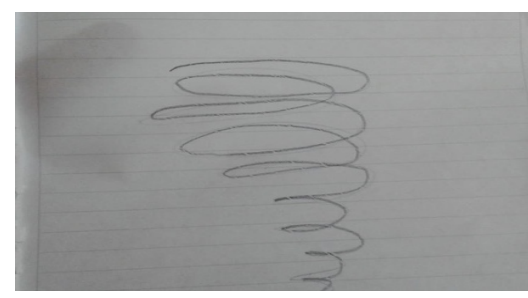




\section{DISCUSIÓN Y CONCLUSIÓN}

El ejercicio de la imaginación activa es una técnica que ayuda en el proceso psicoterapéutico, pero para realizarlo debe tenerse unas precauciones y preparación, porque no es adecuada para personas con una estructura psicótica o estados de ánimo inestables, debido a que puede disociar la psique fácilmente en vez de producir un beneficio para su salud mental; en el caso de los participantes de esta investigación se hizo una evaluación previa, con el fin de identificar quiénes eran aptos para participar en la investigación.

El análisis de las imágenes que se hallaron a partir del ejercicio de imaginación activa y la capacidad simbólica de la psique a partir de imágenes producidas desde el inconsciente colectivo, estas están relacionadas con la incertidumbre que ha producido la pandemia en imágenes de encierro como la cárcel, de inestabilidad como la brújula, metrónomo y de movimiento como las tormentas, tornados, cadenas de ADN en movimiento o aves volando.

Todas están imágenes están asociadas a emociones y sentimientos negativos en relación con el momento histórico con la pandemia que vivimos como humanidad, y como resultado se hallaron que las imágenes que emergieron del ejercicio de imaginación activa son emociones primarias como el miedo y la rabia, y sentimientos como la inseguridad, preocupación, soledad, opresión, desazón e incertidumbre.

\section{REFERENCIAS BIBLIOGRÁFICAS}

Alonso, J. (2004). La psicología analítica de Jung y sus aportes a la psicoterapia. Universitas Psychologica, 3(1), 55-70.

Barbarah, H. (1981). Encuentros con el alma imaginación activa como C.G Jung la desarrolló. Méjico: Fata Morgana.

Retamales, R. (2016). Imaginación activa y dibujos de lo inconsciente. Meditación y contemplación.Monte Carmel: Fonte.

Torres, O. (2018). Revisión de la psicología junguiana y sus posibles nexos con el pensamiento complejo: en la búsqueda de una psicoterapia compleja. Revista Colombiana de Ciencias Sociales, $9(2), 8$ 